\title{
KEMAMPUAN BERNALAR SISWA KELAS V SEKOLAH DASAR PADA SOAL CERITA PERBANDINGAN BILANGAN BULAT
}

\author{
(STUDENTS' REASONING ABILITY OF FIFTH GRADE IN INTEGER \\ COMPARISON WORD PROBLEM)
}

\author{
Rahma Febriyanti ${ }^{1}$ \\ 1Universitas Islam Lamongan, rahmafebriyanti@unisla.ac.id
}

\begin{abstract}
Abstrak. Penalaran siswa merupakan aspek penting dalam mempelajari matematika. Penelitian ini bertujuan mengetahui penalaran siswa kelas $\mathrm{V}$ sekolah dasar pada soal cerita perbandingan bilangan bulat. Sampel penelitian ini yaitu siswa kelas $\mathrm{V}$ yang terdiri dari 20 siswa. Berdasarkan tes matematika dan tes penalaran, selanjutnya dipilih 2 siswa (1 laki-laki dan 1 perempuan) yang memiliki nilai setara sebagai subjek penelitian. Wawancara dilakukan berdasarkan tes penalaran soal cerita perbandingan bilangan bulat. Subjek perempuan memiliki kemampuan bernalar yang baik dengan menggunakan urutan bilangan. Sedangkan subjek laki-laki memiliki kemampuan bernalar yang cukup dengan menggunakan gambar dalam membandingkan bilangan bulat pada soal cerita. Hasil tersebut menyarankan sebaiknya guru melatih siswa untuk lebih mengeksplor penalarannya pada soal cerita.
\end{abstract}

Kata kunci: Penalaran, Soal Cerita, Bilangan Bulat

\begin{abstract}
Students' reasoning is important aspect to learn mathematics. This study to know students' reasoning in integer comparison word problem. The sample were fifth grade that consists of 20 students. Based on mathematics test and reasoning tes, then selected 2 students (boy and girl) that have similar score as research subject. Interview was conducted based on reasoning test. The girl subject has good reasoning ability by using the ordering number. The boy has enough reasoning ability by using picture to compare integer in word problem. This result suggest that teachers should exercise the students to more explore their reasoning in word problem.
\end{abstract}

Keywords: Reasoning, Word Problem, Integer 


\section{PENDAHULUAN}

Salah satu materi yang diajarkan di sekolah dasar yaitu tentang bilangan (Charles, 2005). Pada saat proses pembelajaran, tentunya masih banyak siswa yang kesulitan dalam memodelkan bilangan bulat yang disajikan dalam bentuk soal cerita (Stephan \& Akyuz, 2012). Tidak hanya bilangan bulat positif, siswa juga mengalami kesulitan dalam memahami bilangan bulat negatif. Ketika siswa diminta untuk membandingkan bilangan tersebut, banyak diantara siswa yang menjawab salah(Bishop, Lamb, Philipp, Whitacre, Schappelle, et al., 2014; Bishop, Lamb, Philipp, Whitacre, \& Schappelle, 2014). Kemampuan bernalar siswa dapat diketahi melalui pengerjaan soal-soal, terutama soal yang membutuhkan alasan logis. Salah satu bentuk soal yang dapat digunakan yaitu soal cerita (word problem). Pada soal berbentuk cerita (word problem) terdapat kejadian yang terjadi di kehidupan sehari-hari, sehingga siswa akan merasa tertarik dengan permasalahan yang disajikan dalam bentuk soal cerita (word problem). Soal cerita cenderung lebih sulit diselesaikan karena membutuhkan kemampuan bernalar yang baik (Febriyanti, 2016). Setiap siswa tentu mempunyai berbagai macam cara untuk bernalar dalam membandingkan bilangan bulat. Ada siswa yang menggunakan penalaran berdasarkan urutan maupun penalaran berdasarkan besaran (Febriyanti, 2018). Penalaran merupakan unsur penting yang tidak hanya digunakan untuk menyelesaikan masalah tetapi juga digunakan pada saat kegiatan pembelajaran di kelas. Sudah sejak lama disepakati bahwa penalaran penting dalam matematika, yaitu dalam pembelajaran dan penggunaannya (Conner, Singletary, Smith, Wagner, \& Francisco, 2014). Jika dilihat dari prestasi belajar siswa yang dihubungkan dengan pemecahan masalah serta dikaitkan dengan perbedaan jenis kelamin, dapat ditemukan bahwa siswa laki-laki lebih memiliki ketertarikan dan rasa ingin tahu yang besar terhadap masalah, dan memiliki jalan penyelesaian masalah yang lebih variatif daripada siswa perempuan (OECD, 2014). Dari keberagaman cara yang dilakukan siswa dalam bernalar, maka dapat dilihat sejauh mana kemampuan siswa dalam bernalar. Kemampuan bernalar siswa tentunya dapat dilihat dari bagaimana siswa menyampaikan argumennya. Argumen yang baik dalam bernalar bilangan bulat yaitu menggunakan penalaran berdasar urutan (ordering based reasoning), selain itu ada juga penalaran berdasar besaran (magnitude based reasoning)(Whitacre et al., 2017).

\section{METODOLOGI}

Penelitian ini menggunakan pendekatan deskriptif kualitatif yang bertujuan untuk mendeskripsikan penalaran matematika siswa kelas $\mathrm{V}$ sekolah dasar pada soal cerita perbandingan bilangan bulat, khususnya pada siswa laki-laki an perempuan. Siswa kelas V SD Labschool Unesa yang terdiri dari 20 siswa dipilih karena telah menerima materi perbandingan bilangan bulat. Semua siswa diberi tes matematika dan tes

29 | Jurnal Pendidikan Matematika dan Matematika Vol. I No. 01 Februari 2019 
penalaran soal cerita perbandingan bilangan bulat. Untuk mengetahui lebih dalam mengenai penalaran siswa, 2 siswa (1 laki-laki dan 1 perempuan) yang memiliki nilai setara dipilih sebagai subjek penelitian. Selanjutnya kedua subjek diwawancara berdasarkan hasil tes penalaran soal cerita perbandingan bilangan bulat. Data penelitian diperoleh dari tes penalaran dan wawancara semi terstruktur berdasarkan tes penalaran soal cerita perbandingan bilangan bulat. Berikut indikator kemampuan bernalar siswa pada soal cerita perbandingan bilangan bulat (Whitacre et al., 2017).

Tabel 1. Indikator kemampuan bernalar siswa pada soal cerita perbandingan bilangan bulat

\begin{tabular}{|ll|}
\hline \multicolumn{1}{|c|}{ Cara bernalar } & Argumen yang diberikan \\
\hline urutan & Bilangan bulat positif yang \\
& mendekati nol atau mendekati \\
& bilangan bulat negatif pada \\
& garis bilangan akan lebih kecil \\
& dari bilangan bulat positif lain. \\
& Bilangan bulat negatif selalu \\
& kurang dari bilangan bulat \\
& positif atau nol. Bilangan bulat \\
& positif selalu lebih dari bilangan \\
& bulat negatif atau nol. \\
& Bilangan bulat yang lebih ke \\
& kanan dari bilangan bulat yang \\
& lain pada garis bilangan adalah \\
& lebih besar dari bilangan bulat \\
& yang lain, atau bilangan bulat \\
& yang lebih ke kiri dari bilangan \\
& bulat yang lain pada garis \\
& bilangan adalah kurang dari \\
& bilangan bulat yang lain. \\
& Membandingkan dua bilangan \\
& bulat negatif, bilangan bulat \\
negatif bisa lebih negatif atau \\
kurang negatif dari bilangan \\
bulat negatif lainnya. Jika \\
membandingkan dua bilangan \\
bulat positif, bilangan bulat \\
positif bisa lebih positif atau \\
kurang positif dari bilangan \\
bulat positif lainnya. \\
Membandingkan bilangan bulat \\
tidak nol dengan nol, dengan \\
Bernalar berdasarkan \\
besaran
\end{tabular}




\begin{tabular}{|ll|}
\hline Cara bernalar & \multicolumn{1}{c|}{ Argumen yang diberikan } \\
\hline & alasan bahwa nol tidak \\
& memiliki arti. \\
& Menggambarkan besaran suatu \\
& bilangan bulat pada konteks di \\
& kehidupan sehari-hari. \\
\hline
\end{tabular}

\section{HASIL DAN PEMBAHASAN}

\section{Hasil}

Berdasarkan nilai yang diperoleh dari tes matematika dan tes penalaran, terdapat 5 siswa (2 laki-laki dan 3 perempuan) yang memperoleh nilai setara pada tes matematika dan tes penalaran. Selanjutnya dipilih 1 siswa laki-laki dan 1 siswa perempuan sebagai subjek perempuan berdasarkan saran dari guru matematika. Berikut deskripsi hasil tes penalaran dan wawancara dari subjek perempuan dan subjek laki-laki:

\section{Penalaran Subjek Perempuan (SP)}

Dalam membandingkan dua bilangan bulat yang disajikan dalam soal cerita, SP tidak setuju dengan pernyataan yang diberikan bahwa skor Bella lebih tinggi dibandingkan dengan skor Lisa. Hal ini ditunjukkan SP dengan memberi alasan bahwa selisih skor Bella dan Lisa adalah 8. Selain itu, SP juga menuliskan bilangan dari 1 sampai 20. Pada bilanan 12 dan 20, SP memberi tanda khusus.

\section{Salah, katenon selisih skor bella \& Lis a adalah 8 $123456789104 \sqrt{12} 13141506171819 \sqrt{20}$}

\section{Gambar 1. Penalaran subjek perempuan (SP)}

Berikut wawancara dengan SP.

$\mathrm{P} \quad$ : Mengapa pernyataan yang diberikan salah?

SP : Karena selisih antara skor Bella dan skor Lisa adalah 8.

P : Lalu darimana kamu tahu kalau skor yang diperoleh Lisa lebih besar?

SP : Ya ini dari ini (menunjuk pada bilangan yang 1 sampai 20 yang ditulis)

P : Dimanakah letak bilangan 20 sehingga bisa lebih besar?

SP : Bilangan 20 terletak lebih ke kanan dibandingkan bilangan yang kurang dari 20. Jadi skor Lisa lebih besar dari skor Bella karena Lisa memperoleh skor 20 dan Bella hanya memperoleh skor 12.

P : Apakah bilangan yang terletak lebih ke kanan dari bilangan yang lain artinya akan lebih besar?

31 Jurnal Pendidikan Matematika dan Matematika Vol. I No. 01 Februari 2019 
SP : Iya pasti lebih besar karena kalau ke kanan berarti positifnya semakin besar.

\section{Penalaran Subjek Laki-laki (SL)}

Dalam membandingkan dua bilangan bulat yang disajikan dalam soal cerita, SL tidak setuju dengan pernyataan yang diberikan bahwa skor Bella lebih tinggi dibandingkan dengan skor Lisa. Alasan yang diberikan SL yaitu karena skor Lisa lebih tinggi daripada skor Bella. Untuk memperjelas alasan yang diberikan, SL menggambar pensil dengan keterangan 20 pensil, dan disampingnya SL juga menggambar penggaris dengan disertai keterangan 12 penggaris. Pada gambar yang dibuat oleh SL tidak memberi keterangan apapun yang berkaitan dengan skor Bella dan Lisa.

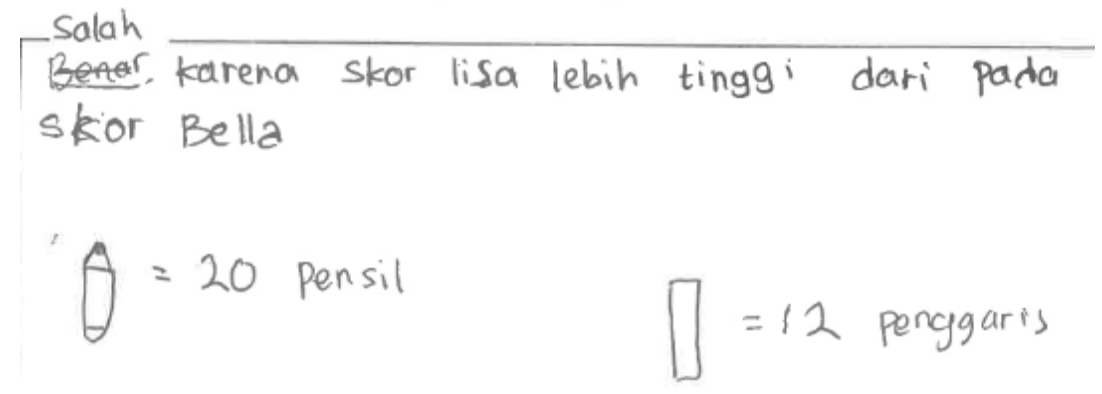

Gambar 2. Penalaran Subjek Laki-laki (SL)

Berikut wawancara dengan SL.

P : Mengapa kamu tidak setuju dengan pernyataan yang diberikan?

SL : Karena skor Lisa lebih tinggi daripada skor Bella.

$\mathrm{P} \quad$ : Bagaimana kamu tahu?

SL : Karena skor Lisa lebih banyak.

$\mathrm{P} \quad$ : Apa maksudnya?

SL : Ya seperti ini (menunjuk pada gambar yang dibuat). Ini misalnya pensil ada 20, terus penggaris ada 12. Pasti pensil yang 20 lebih banyak daripada penggaris 12 .

$\mathrm{P} \quad$ : Apa hubungannya pensil dan penggaris dengan skor Lisa dan Bella?

SL : Ya dimisalkan yang skor Lisa seperti pensil, skor Bella seperti penggaris.

\section{PEMBAHASAN}

Tujuan dari penelitian ini yaitu mengetahui kemmapuan bernalar siswa kelas V laki-laki dan perempuan, terutama dalam menyelesaikan masalah perbandingan bilangan bulat yang disajikan dalam bentuk soal cerita. Pada hasil yang disajikan, siswa diminta untuk membandingkan dua bilangan bulat positif. Berdasarkan hasil tes penalaran dan wawancara yang dilakukan pada subjek perempuan (SP) dan subjek laki- 
laki (SL), terlihat bahwa terdapat perbedaan pada argumen yang diberikan. Berikut pembahasan tentang penemuan kemampuan bernalar siswa.

Pada jawaban SP dituliskan urutan bilangan dari 1 sampai 20. Tujuan SP menuliskan urutan bilangan ini yaitu untuk menunjukkan letak skor peserta yang diberikan pada soal. Setalah menuliskan semua bilangan 1 sampai 20. SP memberi tanda khusus pada bilangan 12 dan 20 . Hal ini bertujuan untuk menandai letak skor yang diperoleh Bella yaitu 12 dan skor yang diperoleh Lisa yaitu 20. SP menjelaskan bahwa skor Lisa berada lebih ke kanan daripada skor Bella. Sehingga SP menyatakan bahwa skor yang diperoleh Lisa lebih besar. Selain itu, SP juga memberi argumen bahwa bilangan yang terletak semakin ke kanan akan bernilai semakin positif (Bofferding, 2014). Jadi dapat disimpulkan bahwa kemampuan SP dalam bernalar baik karena sudah menggunakan alasan yang logis yaitu dengan penalaran berbasis urutan, dimana alasan ini bertujuan untuk menunjukkan bilangan yang satu apakah lebih besar daripada bilangan yang lain (Whitacre et al., 2017).

Sedangkan pada jawaban SL, digambarkan dua benda yang tidak berkitan dengan soal cerita yang diberikan. Pada soal cerita membahas mengenai skor peserta pada sebah perlombaan. Tetapi pada saat menjawab pertanyaan yang diberikan, SL memberi argumen dengan menggambarkan pensil serta penggaris. Dapat dilihat bahwa dalam bernalar, SL mengaitkan dengan konteks lain di lingkungan sekitarnya yaitu alat-alat tulis yang ia gunakan (Whitacre et al., 2012). Dengan kata lain, SL menggunakan kuantitas suatu benda untuk membandingkan dua bilangan bulat.

\section{KESIMPULAN}

Penelitian ini menjelaskan bagaimana kemampuan bernalar siswa pada perbandingan bilangan bulat yang disajikan dalam bentuk soal cerita. Pada saat menjawab pertanyaan yang diberikan, siswa perempuan dan siswa laki-laki mengemukakan alasannya secara berbeda, tetapi mengarah pada jawaban yang benar. Siswa perempuan memiliki kemampuan bernalar yang baik karena mendasarkan alasan yang diberikan dengan urutan bilangan pada garis bilangan. Sedangkan siswa laki-laki memiliki kemampuan bernalar yang cukup baik pula karena mendasarkan alasan yang diberikan melalui gambar. Artinya kedua siswa telah dapat menggunakan penalaran yang baik. Kami menyajikan hasil penelitian ini untuk guru matematika yang bertujuan menginformasikan kemampuan bernalar siswa tentang perbandingan bilangan bulat dan guru sebaiknya lebih mengeksplor kemampuan bernalar siswa dalam menyelesaikan masalah matematika dalam bentuk soal cerita. 


\section{DAFTAR RUJUKAN}

Bishop, J. P., Lamb, L. L., Philipp, R. A., Whitacre, I., \& Schappelle, B. P. (2014). Using order to reason about negative numbers: The case of Violet. Educational Studies in Mathematics, 86(1), 39-59. https://doi.org/10.1007/s10649-013-9519-x

Bishop, J. P., Lamb, L. L., Philipp, R. A., Whitacre, I., Schappelle, B. P., \& Lewis, M. L. (2014). Obstacles and Affordances for Integer Reasoning: An Analysis of Children's Thinking and the History of Mathematics. Source: Journal for Research in Mathematics Education, 45(1), 19-61. https://doi.org/10.5951/jresematheduc.45.1.0019

Bofferding, L. (2014). Negative Integer Understanding : Characterizing First Graders ' Mental Models. Journal for Research in Mathematics Education, 45(2), 194-245. https:/ / doi.org/10.5951/jresematheduc.45.2.0194

Charles, R. I. (2005). Big ideas and understandings as the foundation for elementary and middle school mathematics. Journal of Mathematics Education Leadership, 7(3), 9-24. Retrieved from http:/ / www.btschools.org/154110830215321660/lib/15411083021532 1660/NCSMJournal_Big_Ideas.pdf

Conner, A. M., Singletary, L. M., Smith, R. C., Wagner, P. A., \& Francisco, R. T. (2014). Identifying Kinds of Reasoning in Collective Argumentation. Mathematical Thinking and Learning, 16(3), 181-200. https:/ / doi.org/10.1080/10986065.2014.921131

Febriyanti, R. (2016). Profil Pemecahan Masalah Matematika Siswa dalam Menyelesaikan Soal Cerita Ditinjau dari Perbedaan Jenis Kelamin. Jurnal Ilmiah Pendidikan Matematika, 2, 81-89.

Febriyanti, R. (2018). The Way of Students' Reasoning of Elementary Students in Solving Integer Problem The Way of Students ' Reasoning of Elementary Students in Solving Integer Problem. Journal of Physics: Conference Series, $1108 . \quad$ https://doi.org/10.1088/17426596/1108/1/01033

OECD. (2014). PISA 2012 Results: Creative Problem Solving: Students' Skills in Tackling Real-Life Problems. (http://www.oecd.org/pisa/keyfindings/pisa-2012-results-volumev.htm/, diakses pada 30 Januari 2019).

Stephan, M., \& Akyuz, D. (2012). A Proposed Instructional Theory for Integer Addition and Subtraction, National Council of Teachers of Mathematics, 43(4), 428-464.

Whitacre, I., Azuz, B., Lamb, L. L. C., Bishop, J. P., Schappelle, B. P., \& Philipp, R. A. (2017). Integer comparisons across the grades: Students' justifications and ways of reasoning. Journal of Mathematical Behavior, 
45, 47-62. https://doi.org/10.1016/j.jmathb.2016.11.001

Whitacre, I., Bishop, J. P., Lamb, L. L. C., Philipp, R. A., Schappelle, B. P., \& Lewis, M. L. (2012). Happy and sad thoughts: An exploration of children's integer reasoning. Journal of Mathematical Behavior, 31(3), 356-365. https://doi.org/10.1016/j.jmathb.2012.03.001 